\title{
Kinetic Studies on Hexavalent Chromium Reduction
}

\author{
Ankita Basu, Bidyut Saha* \\ Department of Chemistry, University of Burdwan, Golapbag, India \\ E-mail:b_saha31@rediffmail.com \\ Received January 10, 2009; revised February 21, 2009; accepted February 23, 2009
}

\begin{abstract}
$\mathrm{Cr}(\mathrm{VI})$ is a known human carcinogen. It is a wide spread environmental contaminant as it is extensively used in different industry. The kinetic study of reduction of $\mathrm{Cr}(\mathrm{VI})$ by a known organic substance, 1-butanol in micellar media have been studied spectrophotometrically. The reduction of $\mathrm{Cr}$ (VI) to $\mathrm{Cr}$ (III) occurs in a microheterogeneous system in cell cytoplasm. As micelles are considered to mimic the cellular membranes, the reduction process occurring in the micellar system is considered as a model to obtain insight in to the reduction process prevailing in body systems. Micellar media is also a probe to establish the mechanistic paths of reduction of $\mathrm{Cr}(\mathrm{VI})$ to $\mathrm{Cr}(\mathrm{III})$ and the effects of some electrolytes common to a biological systems are studied to establish the proposed reaction mechanism strongly. The overall reaction follows a first order dependency on substrate and hexavalent chromium and second order dependency on hydrogen ion. Suitable surfactant $\&$ suitable concentration of electrolyte enhance the rate of the reaction.
\end{abstract}

Keywords: Pollution, Carcinogen, Cr(VI), Oxidation; Kinetics, Surfactant, Electrolyte

\section{Introduction}

Water pollution by chromium is of considerable concern, as this metal has found widespread use in electro plating, leather tanning, metal finishing, nuclear power plant, textile industries and chromate preparation [1]. The effluents from these industries contain $\mathrm{Cr}(\mathrm{III})$ and $\mathrm{Cr}(\mathrm{VI})$ at concentrations ranging from ten to hundreds of $\mathrm{mg} / \mathrm{L}$ [2]. The hexavalent form is 500 times more toxic than the trivalent [3]. Though chromium exists in nine valence states ranging from -2 to $+6, \mathrm{Cr}(\mathrm{III})$ and $\mathrm{Cr}(\mathrm{VI})$ are of major environmental significance because of their stability in the natural environment [4]. The chromate anion is highly soluble and therefore can overcome the cellular permeability barrier, entering via sulphate transport pathways since it bears structural similarity with $\mathrm{SO}_{4}^{2-}$ [5-7]. It has been reported that hexavalent chromium causes lung cancer, chromate ulcer, perforation of nasal septum and kidney damage in humans and it is also toxic to other organism as well $[8,9]$. Chromium in its trivalent form is an essential micronutrient for many microorganisms, relatively insoluble in water.

A number of treatment methods for removal of metal ions from aqueous solutions have been reported mainly reduction, ion exchange, solvent extraction, reverse osmosis, chemical precipitation and adsorption [10]. In the reduction followed by chemical precipitation method
[11], $\mathrm{Cr}(\mathrm{VI})$ is reduced to $\mathrm{Cr}(\mathrm{III})$ first, then lime is added to precipitate chromium as hydroxide.

In this paper, we studied kinetics and mechanism of $\mathrm{Cr}(\mathrm{VI})$ reduction to $\mathrm{Cr}(\mathrm{III})$ by an alcohol in presence of micelle and electrolyte because micelle [12-14] and electrolyte [15] substantiate the reaction mechanism. The outcome of such an exercise will certainly influence the detoxification methods.

\section{Experimental}

\subsection{Materials and Reagents}

Butan-1-ol (AR, Merck, India), $\mathrm{K}_{2} \mathrm{Cr}_{2} \mathrm{O}_{7}$ (AR, BDH, India), N-cetyl pyridinium chloride (CPC) (AR, SRL, India), Sodium dodecyl sulphate (SDS) (AR, SRL, India), TX-100 (AR, SRL, India), NaCl (AR, Merck, India), $\mathrm{NH}_{4} \mathrm{Cl}$ (AR, Ranbaxy, India) and other chemicals used were of highest purity available commercially. Solutions were prepared in double distilled water.

\subsection{Procedure and Kinetic Measurements}

Under the kinetic conditions, solutions of the oxidant and mixtures containing the known quantities of the substrate(s) (i.e., butan-1-ol) (under the conditions $[\mathrm{S}]_{\mathrm{T}}>>$ $\left.[\mathrm{Cr}(\mathrm{VI})]_{\mathrm{T}}\right)$, acid and the other necessary chemicals were 
separately thermostated $\left( \pm 0.1^{\circ} \mathrm{C}\right)$. The reaction was initiated by mixing the requisite amounts of the oxidant with the reaction mixture. Zero time was set when half of the required volume of the oxidant had been added. The progress of the reaction was followed by monitoring the decay of oxidant [Cr(VI)] at $415 \mathrm{~nm}$ at different time intervals ( 2 minutes) with a UV-VIS spectrophotometer [UV-2450(SHIMADZU)]. Quartz cuvettes of path length $1 \mathrm{~cm}$ were used. The observed pseudo-first-order rate constants $\left[k_{\mathrm{obs}}\left(\mathrm{s}^{-1}\right)\right]$ were determined from the linear part of the plots of $\ln \left(\mathrm{A}_{415}\right)$ versus time $(\mathrm{t})$. Reproducible results giving first-order plots (co-relation co-efficient, $r \geq$ 0.998 ) were obtained for each reaction run. A large excess ( $\geq 15$-fold) of reductant was used in all kinetic runs. No interference due to other species at $415 \mathrm{~nm}$ was verified. Under the experimental conditions, the possibility of decomposition of the surfactants by $\mathrm{Cr}(\mathrm{VI})$ was investigated and the rate of decomposition in this path was found to be kinetically negligible.

\subsection{Product Analysis and Stoichiometry}

Under the kinetic condition (i.e., [butanol $\left.]_{\mathrm{T}}>>[\mathrm{Cr}(\mathrm{VI})]_{\mathrm{T}}\right)$ butanol oxidizes to butanal and estimation of the reaction products was carried by gravimetrically as 2,4-dinitrophenylhydrazone. In a typical experimental set, $10 \mathrm{ml}$ of $0.06 \mathrm{~mol} \cdot \mathrm{L}^{-1} \mathrm{Cr}(\mathrm{VI})$ in $1.0 \mathrm{~mol} \cdot \mathrm{L}^{-1} \mathrm{H}_{2} \mathrm{SO}_{4}$ was added to $40 \mathrm{~mL}$ of $0.2 \mathrm{~mol} \cdot \mathrm{L}^{-1}$ butanol and the reaction was allowed to proceed to completion. Completion of the reaction was indicated by the disappearances of $\mathrm{Cr}(\mathrm{VI})$ color. Then the reaction mixture was added slowly with stirring to $60 \mathrm{~mL}$ of a saturated solution of 2,4-dinitrophenylhydrazine in $2.0 \mathrm{~mol} \cdot \mathrm{L}^{-1} \mathrm{HCl}$. After storing for about $1 \mathrm{~h}$ in an ice-bath, the precipitate was collected weighed sintered glass crucible, washed with $2.0 \mathrm{~mol} \cdot \mathrm{L}^{-1} \mathrm{HCl}$ followed by water and dried to a constant weight at $100-105^{\circ} \mathrm{C}$ and recrystallized from ethanol. The hydrazone showed melting point $123-125^{\circ} \mathrm{C}$ [16]. The found ratio, $[\mathrm{Cr}(\mathrm{VI})]_{\mathrm{T}} /[\text { Carbonyl compound }]_{\mathrm{T}} \approx 2 / 3$ (from 3 independent determinations) supports the following Stoichiometry:

$$
\begin{aligned}
& 3 \mathrm{CH}_{3} \mathrm{CH}_{2} \mathrm{CH}_{2} \mathrm{OH}+2 \mathrm{HCrO}_{4}+8 \mathrm{H}^{+} \rightarrow \\
& 3 \mathrm{CH}_{3} \mathrm{CH}_{2} \mathrm{CH}_{2} \mathrm{CHO}+2 \mathrm{Cr}(\mathrm{III})+8 \mathrm{H}_{2} \mathrm{O}
\end{aligned}
$$

\section{Results and Discussion}

\subsection{Dependence on $\mathrm{Cr}(\mathrm{VI})$}

Under the experimental condition, $[\text { Butan-1-ol }]_{\mathrm{T}}>$ $[\mathrm{Cr}(\mathrm{VI})]_{\mathrm{T}}$, the rate of disappearance of $\mathrm{Cr}(\mathrm{VI})$ shows a first order dependency on $\mathrm{Cr}(\mathrm{VI})$. This dependence is also maintained in the presence of cationic surfactant (CPC), anionic surfactant (SDS) and neutral surfactant (TX-100) (Figure 1).

\subsection{Dependence on $[\text { Substrate }]_{\mathrm{T}}$ i.e., $[\text { Butan-1-ol }]_{\mathrm{T}}$}

From the plot of $k_{\mathrm{obs}}$ vs [Butan-1-ol] $]_{\mathrm{T}}$ (Figure 2), it is established that the path shows a first order dependency on $[\text { substrate }]_{\mathrm{T}}$, i.e., [butan-1-ol $]_{\mathrm{T}}$.

$$
k_{\mathrm{obs}}=k_{\mathrm{S}}[\mathrm{S}]_{\mathrm{T}} \text {. }
$$

The above first order dependence on $[\text { substrate }]_{\mathrm{T}}$ is also maintained in the presence of surfactant like CPC, SDS, TX-100.

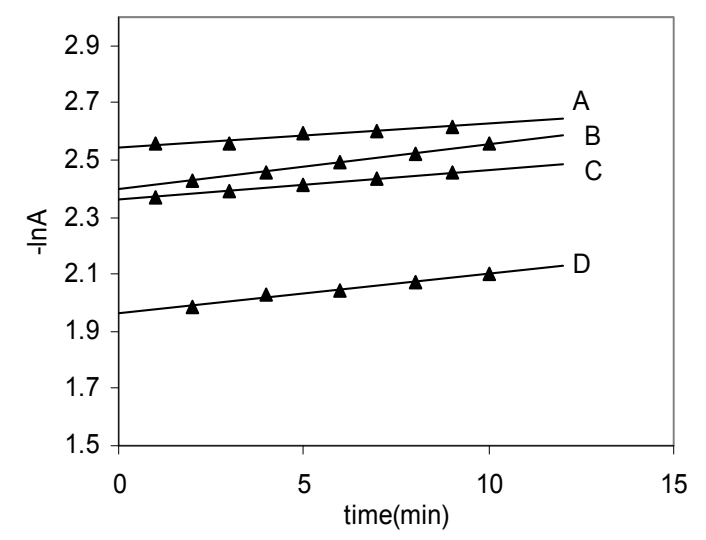

Figure 1. Some representative first-order plots to evaluate the pseudo-first-order rate constants $\left(k_{\text {obs }}\right)$ for the $\mathrm{Cr}(\mathrm{VI})$ oxidation of 1-butanol at $30^{\circ} \mathrm{C}$. Dependence of absorbance of $\mathrm{Cr}(\mathrm{VI})$ on time (min) for the oxidation of 1-butanol at $30^{\circ} \mathrm{C}$. $[\mathrm{Cr}(\mathrm{VI})]=5 \times 10^{-4} \mathrm{~mol} \cdot \mathrm{L}^{-1},[1-$ butanol $]=1500 \times 10^{-4} \mathrm{~mol} \cdot \mathrm{L}^{-1}$, $\left[\mathrm{H}_{2} \mathrm{SO}_{4}\right]=0.50 \mathrm{~mol} \cdot \mathrm{L}^{-1} \cdot \mathrm{A}:[\mathrm{SDS}]_{\mathrm{T}}=0 \mathrm{~mol} \cdot \mathrm{L}^{-1},[\mathrm{CPC}]_{\mathrm{T}}=2 \times$ $10^{-3} \mathrm{~mol} \cdot \mathrm{L}^{-1},[\mathrm{TX}-100]_{\mathrm{T}}=0 \mathrm{~mol} \cdot \mathrm{L}^{-1} . \mathrm{B}:[\mathrm{SDS}]_{\mathrm{T}}=0 \mathrm{~mol} \cdot \mathrm{L}^{-1}$, $[\mathrm{CPC}]_{\mathrm{T}}=0 \mathrm{~mol} \cdot \mathrm{L}^{-1},[\mathrm{TX}-100]_{\mathrm{T}}=\mathbf{2} \times \mathbf{1 0}^{-2} \mathrm{~mol} \cdot \mathrm{L}^{-1} . \mathrm{C}:[\mathrm{SDS}]_{\mathrm{T}}$ $=0 \mathrm{~mol} \cdot \mathrm{L}^{-1},[\mathrm{CPC}]_{\mathrm{T}}=0 \mathrm{~mol} \cdot \mathrm{L}^{-1},[\mathrm{TX}-100]_{\mathrm{T}}=0 \mathrm{~mol} \cdot \mathrm{L}^{-1} . \mathrm{D}$ : $[\mathrm{SDS}]_{\mathrm{T}}=2 \times 10^{-2} \mathrm{~mol} \cdot \mathrm{L}^{-1},[\mathrm{CPC}]=0 \mathrm{~mol} \cdot \mathrm{L}^{-1},[\mathrm{TX}-100]_{\mathrm{T}}=0$ $\mathbf{m o l} \cdot \mathbf{L}^{-1}$.

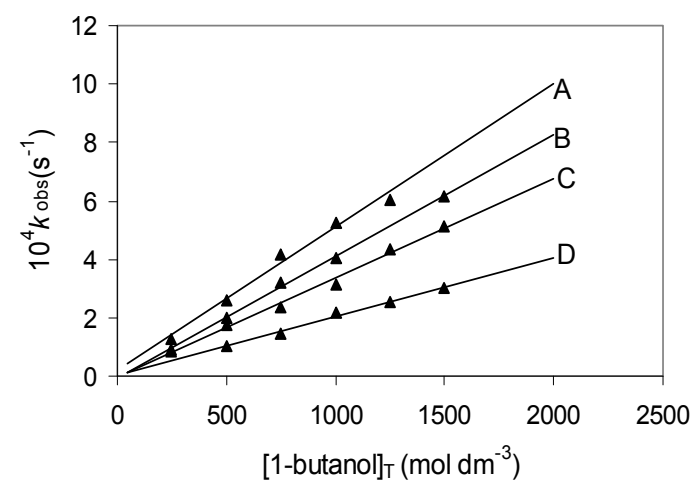

Figure 2. Dependence of $\boldsymbol{k}_{\text {obs }}$ on [1-butanol] for the Cr(VI) oxidation of 1-butanol at $30^{\circ} \mathrm{C}$. $[\mathrm{Cr}(\mathrm{VI})]=5 \times 10^{-4} \mathrm{~mol} \cdot \mathrm{L}^{-1}$, $\left[\mathrm{H}_{2} \mathrm{SO}_{4}\right]=0.50 \mathrm{~mol} \cdot \mathrm{L}^{-1} \cdot \mathrm{A}:[\mathrm{SDS}]_{\mathrm{T}}=2 \times 10^{-2} \mathrm{~mol} \cdot \mathrm{L}^{-1},[\mathrm{CPC}]_{\mathrm{T}}$ $=0 \mathrm{~mol} \cdot \mathrm{L}^{-1},[\mathrm{TX}-100]_{\mathrm{T}}=0 \mathrm{~mol} \cdot \mathrm{L}^{-1} . \mathrm{B}:[\mathrm{SDS}]_{\mathrm{T}}=\mathbf{0} \mathrm{mol} \cdot \mathrm{L}^{-1}$, $[\mathrm{CPC}]_{\mathrm{T}}=0 \mathrm{~mol} \cdot \mathrm{L}^{-1},[\mathrm{TX}-100]_{\mathrm{T}}=2 \times 10^{-2} \mathrm{~mol} \cdot \mathrm{L}^{-1} . \mathrm{C}:[\mathrm{SDS}]_{\mathrm{T}}$ $=0 \mathrm{~mol} \cdot \mathrm{L}^{-1},[\mathrm{CPC}]_{\mathrm{T}}=0 \mathrm{~mol} \cdot \mathrm{L}^{-1},[\mathrm{TX}-100]_{\mathrm{T}}=0 \mathrm{~mol} \cdot \mathrm{L}^{-1} . \mathrm{D}$ : $[\mathrm{SDS}]_{\mathrm{T}}=0 \mathrm{~mol} \cdot \mathrm{L}^{-1},[\mathrm{CPC}]=\mathbf{2} \times 10^{-3} \mathrm{~mol} \cdot \mathrm{L}^{-1},[\mathrm{TX}-100]_{\mathrm{T}}=0$ mol $\cdot \mathbf{L}^{-1}$. 


\subsection{Dependence on $\left[\mathrm{H}^{+}\right]_{\mathrm{T}}$}

The acid dependence was followed in aqueous $\mathrm{HClO}_{4}$ medium at fixed $\mathrm{Cr}(\mathrm{VI})$ and [substrate]. From the experimental fit (Figure 3), the observation is

$$
k_{\mathrm{obs}}=k_{\mathrm{H}}\left[\mathrm{H}^{+}\right]^{2} \text {. }
$$

Thus the acid variation shows a second order dependence on $\left[\mathrm{H}^{+}\right]$ion. The above second order dependency is also maintained in presence of surfactants.

\subsection{Effects of Surfactants}

\subsubsection{Effects of CPC}

Cetyl Pyridinium Chloride (CPC, a representative cationic surfactant is found to retard the reaction path. Plot of $k_{\mathrm{obs}}$ vs $[\mathrm{CPC}]_{\mathrm{T}}$ (Figure 4) shows a continuous decrease and finally it tends to level off at higher concentration of CPC. The observation is identical to that observed by Bunton and Cerichelli [17] in the oxidation of ferrocene by ferric salt salts in the presence of cationic

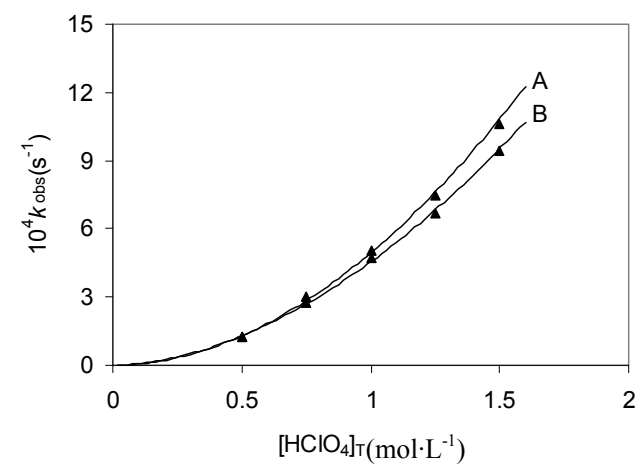

Figure 3. Dependence of $\boldsymbol{k}_{\text {obs }}$ on $\left[\mathrm{H}^{+}\right]$for the $\mathrm{Cr}(\mathrm{VI})$ oxidation of 1-butanol $30^{\circ} \mathrm{C}$. A: $[\mathrm{Cr}(\mathrm{VI})]=5 \times 10^{-4} \mathrm{~mol} \cdot \mathrm{L}^{-1}$, $\left[1-\right.$ butanol] $=500 \times 10^{-4} \mathrm{~mol} \cdot \mathrm{L}^{-1},[\mathrm{SDS}]=2 \times 10^{-2} \mathrm{~mol} \cdot \mathrm{L}^{-1} . \mathrm{B}$ : $[\mathrm{Cr}(\mathrm{VI})]=5 \times 10^{-4} \mathrm{~mol} \cdot \mathrm{L}^{-1},[1-$ butanol $]=500 \times 10^{-4} \mathrm{~mol} \cdot \mathrm{L}^{-1}$, $[\mathrm{SDS}]=0 \mathrm{~mol} \cdot \mathrm{L}^{-1}$.

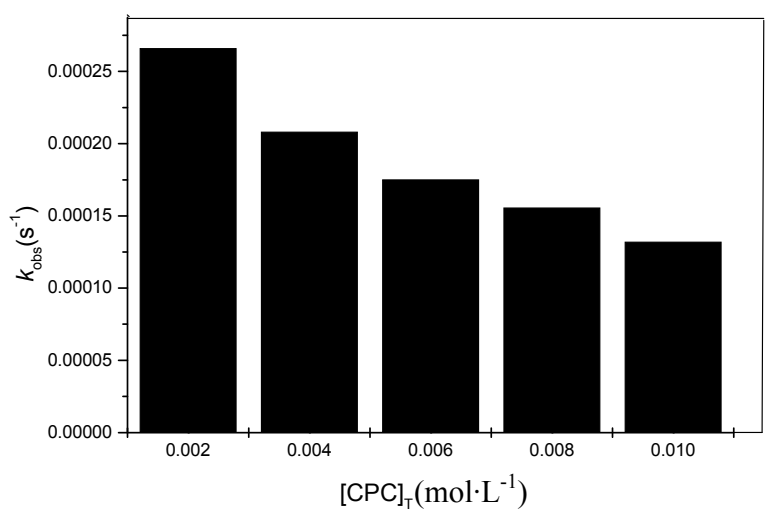

Figure 4. Dependence of $\boldsymbol{k}_{\mathrm{obs}}$ on $[\mathrm{CPC}]_{\mathrm{T}}$ for the $\mathrm{Cr}(\mathrm{VI})$ oxidation of 1-butanol at $30^{\circ} \mathrm{C} .[\mathrm{Cr}(\mathrm{VI})]=5 \times 10^{-4} \mathrm{~mol} \cdot \mathrm{L}^{-1}$, $[1-$ butanol $]=1000 \times 10^{-4} \mathrm{~mol} \cdot \mathrm{L}^{-1},\left[\mathrm{H}_{2} \mathrm{SO}_{4}\right]=0.50 \mathrm{~mol} \cdot \mathrm{L}^{-1}$. surfactant cetyl trimethyl ammonium bromide (CTAB).

\subsubsection{Effects of SDS}

Sodium dodecyl sulphate(SDS, a representative anionic surfactant) accelerate the reaction path. The plot of $k_{\text {obs }}$ vs $[\mathrm{SDS}]_{\mathrm{T}}$ (Figure 5) shows a continuous increase up to the concentration of SDS.

\subsubsection{Effects of $T X-100$}

Triton X-100(TX-100, a representative neutral surfactant) accelerates the reaction path. But the acceleration rate in TX-100 is less than that of SDS. The plot of $k_{\mathrm{obs}}$ vs $[\mathrm{TX}-100]_{\mathrm{T}}$

Figure 6 shows a continuous increase up to the concentration of TX-100.

\subsubsection{Test for Acrylonitrile Polymerization}

Under the experimental conditions, the existence of free radical was indicated by polymerization of acrylonitrile under a nitrogen atmosphere.

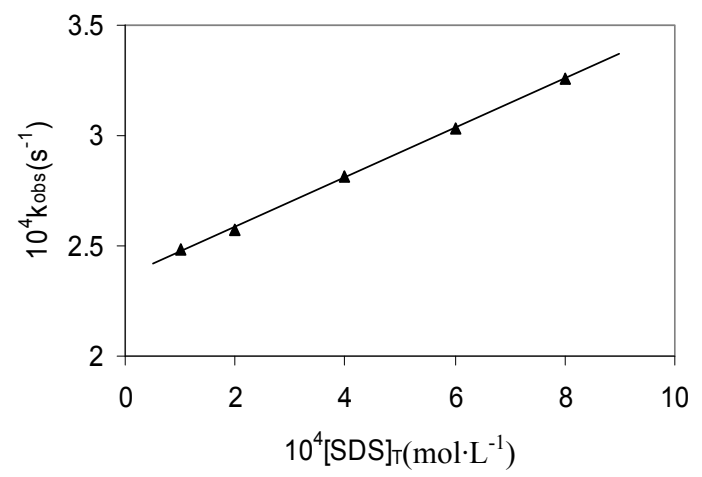

Figure 5. Dependence of $\boldsymbol{k}_{\text {obs }}$ on [SDS] T for the $\mathrm{Cr}(\mathrm{VI})$ oxidation of 1-butanol at $30^{\circ} \mathrm{C} .[\mathrm{Cr}(\mathrm{VI})]=5 \times 10^{-4} \mathrm{~mol} \cdot \mathrm{L}^{-1}$, $[1-$ butanol $]=500 \mathrm{~mol} \cdot \mathrm{L}^{-1},\left[\mathrm{H}_{2} \mathrm{SO}_{4}\right]=0.50 \mathrm{~mol} \cdot \mathrm{L}^{-1}$.

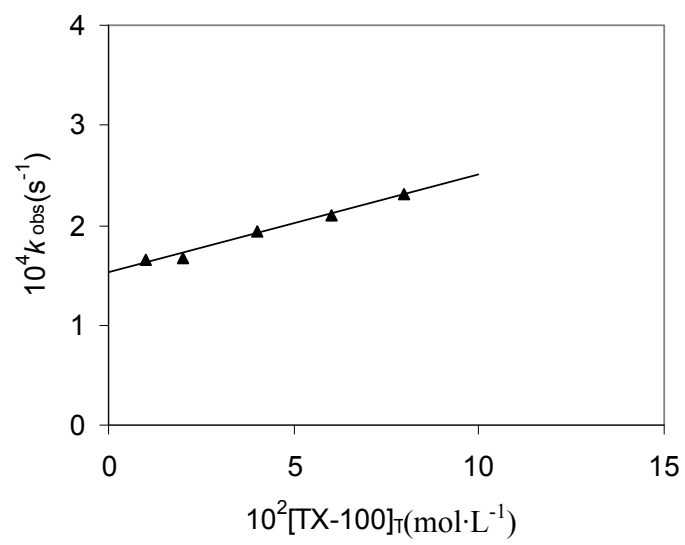

Figure 6. Dependence of $k_{\mathrm{obs}}$ on $[\mathrm{TX}-100]_{\mathrm{T}}$ for the $\mathrm{Cr}(\mathrm{VI})$ oxidation of 1-butanol at $30^{\circ} \mathrm{C}$. $[\mathrm{Cr}(\mathrm{VI})]=5 \times 10^{-4} \mathrm{~mol} \cdot \mathrm{L}^{-1}$, $[1-$ butanol $]=500 \times 10^{-4} \mathrm{~mol} \cdot \mathrm{L}^{-1},\left[\mathrm{H}_{2} \mathrm{SO}_{4}\right]=0.50 \mathrm{~mol} \cdot \mathrm{L}^{-1}$. 


\subsubsection{Mechanism and Interpretation}

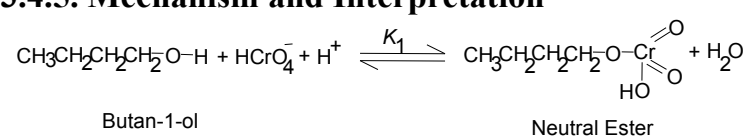

$$
\begin{aligned}
& \text { Neutral Ester }
\end{aligned}
$$

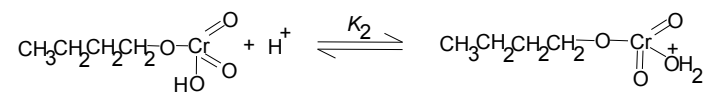

$$
\begin{aligned}
& \text { Neutral Ester } \\
& \mathrm{CH}_{3} \mathrm{CH}_{2} \mathrm{CH}_{2} \mathrm{CH}_{\text {Butanal }}^{\mathrm{O}} \underset{\mathrm{OH}_{2}}{\mathrm{O}} \underset{\substack{\mathrm{O} \\
\mathrm{H}_{2}}}{\mathrm{CH}_{3} \mathrm{CH}_{2} \mathrm{CH}_{2} \mathrm{CH}=\mathrm{O}}+\mathrm{Cr}^{\mathrm{IV}}+\mathrm{H}^{+}
\end{aligned}
$$

Scheme 1. Cr(VI) reduction by butan-1-ol.

Scheme 1 leads to the flowing rate law

$$
k_{\mathrm{obs}}=(2 / 3) k K_{1} K_{2}[\mathrm{~S}]_{\mathrm{T}}\left[\mathrm{H}^{+}\right]^{2}
$$

The pseudo-first-order rate constants $\left(k_{\mathrm{obs}}\right)$ in the presence of various concentrations of different types of surfactants, SDS, CPC, TX-100 are represented in Figures 4-6. The pseudo phase ion-exchange (PIE) [18] model is applied most widely in micellar catalysis. The basic assumption of the PIE is as follows:

1) Micelles act as a separate phase from water, all reactants are distributed quickly between water and micellar phase, and the reaction rate can be considered as the sum of that in two phases.

2) The reaction in the micellar pseudo phase occurs mainly at micelle surface.

3) The reactant ions and the inert ions compete at the charged micellar surface.

The data reveal that SDS and TX-100 accelerate the rate where as $\mathrm{CPC}$ decreases the rate. The rate acceleration is higher in the case of SDS than TX-100. This can be explained by Schemes 2 and 3 .

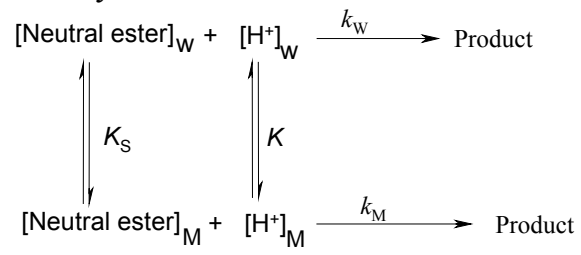

Scheme 2. Partitioning of the reactive species between the aqueous and micellar phases.

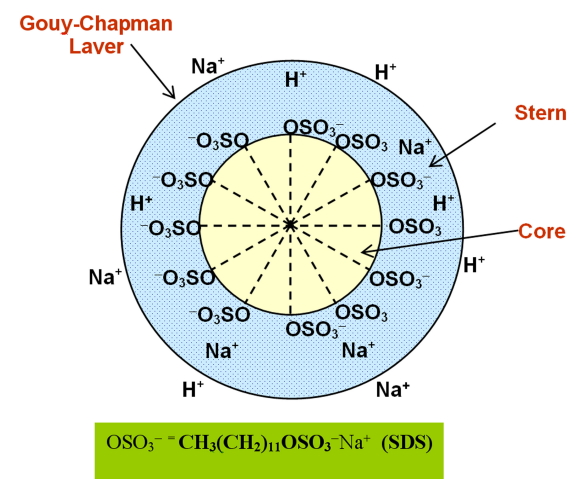

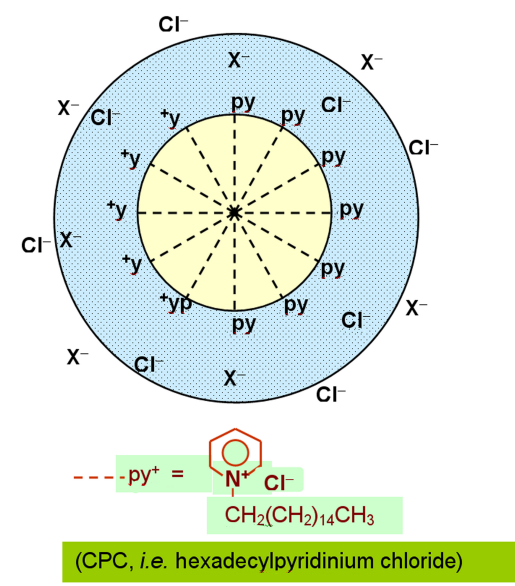

Scheme 3. Structural representation of anionic \& cationic surfactants.

Ever since J. W. Mc Bain proposed the presence of molecular aggregates in soap solution on the basis of the unusual changes in electrical conductivity observed with changing soap concentration [19], the structure of micellar aggregates has been a matter of discussion. G. S. Hartley proposed that micelles are spherical with charged groups situated at the micellar surface [20], whereas Mc Bain suggested that lamellar and spherical forms coexist [21]. X-ray studies by Harkins et al., [22,23] then suggested the sandwich or lamellar model. Later, P. Debye and E. W. Anacker proposed that micelles are rod-shaped rather than spherical or disk like [24]. The cross section of such a rod would be circular, with the polar heads of the detergent lying on the periphery and the hydrocarbon tails filling the interior. The ends of the rod would almost certainly have to be rounded and polar. In 1956, Hartley's spherical micelle model was established by I. Reich [25] from the view point of entropy, and the spherical form is now generally accepted as approximating the actual structure. The formation of micelles by ionic surfactants is ascribed to a balance between hydrocarbon chain attraction and ionic repulsion. The net charge of micelles is less than the degree of micellar aggregates, indicating that a large fraction of counter ions remains associated with the micelle; these counter ions form the Stern layer at the micellar surface. For nonionic surfactants, however, the hydrocarbon chain attraction is opposed by the requirements of hydrophilic groups for hydration and space. Therefore, the micellar structure is determined by equilibrium between the repulsive forces among hydrophilic groups and the short-range attractive forces among hydrophobic groups. For bimolecular reactions inhibition arises from incorporation of one reactant into the micellar pseudo phase and exclusion of the other from it. Catalysis is apparently caused, for the most part, by concentration of the two reactants into a small volume in the micellar Stern layer [26].

The substrate is partitioned in the Stern layer of the 
micellar phase. SDS being an anionic surfactant, owing to the electrostatic attraction between the positively charged $\left[\mathrm{H}^{+}\right]$species and negatively charged micellar head groups. $\left[\mathrm{H}^{+}\right]$easily attaches to the Stern layer of the micelle. The reaction takes place in both the micellar and aqueous media. The observed rate acceleration is due to the favored reaction in the micellar phase, where both $\mathrm{H}^{+}$ and the neutral ester are preferably accumulated. In the case of TX-100, $\mathrm{H}^{+}$also attaches to the Stern layer of the micelle, but the amount is less compared to SDS because TX-100 is a neutral surfactant, so no electrostatic attraction takes place. CPC is a cationic surfactant and consequently due to the electrostatic repulsion between the positively charged $\left[\mathrm{H}^{+}\right]$species and positively charged micellar head group, $\left[\mathrm{H}^{+}\right]$does not attaches to the Stern layer of micelle through the substrate. The reaction takes place only in aqueous media, which is depleted in the substrate concentration.

\subsubsection{Effect of Added Electrolyte}

Experimental evidence has shown that electrolyte inhibition of micellar catalysis is a general phenomenon [27-29] with one apparent exception [30]. Here we report a system which connects inhibition and enhancement. The proposed study has taken into consideration for better under standing of $\mathrm{Cr}$ (VI) carcinogenity. The added electrolytes are common to biological systems. Electrolyte inhibition is rationalized by assuming that a counter ion competes with an ionic reagent (e.g., $\mathrm{OH}^{-}, \mathrm{H}_{3} \mathrm{O}^{+}$, and $\mathrm{X}^{-}$) for a site on the ionic micelle [31]. Enhancement of micellar catalysis by added salt is caused by their changing the shape or reducing the charge density of the micelle. Salts decrease the cmc (critical micelle concentration) and increase the aggregation number of ionic micelles [31-33] probably because increased screening by the counter ions decreases the effective charge density of the micelle. Added salts are very common sodium chloride $(\mathrm{NaCl})$ and ammonium chloride $\left(\mathrm{NH}_{4} \mathrm{Cl}\right)$. In SDS medium the rate is retarded up to $0.7 \mathrm{~mol} \cdot \mathrm{L}^{-1}$ solution of $\mathrm{NH}_{4} \mathrm{Cl}$ and $0.8 \mathrm{~mol} \cdot \mathrm{L}^{-1}$ solution of $\mathrm{NaCl}$. After that the rate is increased (Figure 7). $\mathrm{Up}$ to $0.7 \mathrm{~mol} \cdot \mathrm{L}^{-1}$ of $\mathrm{NH}_{4} \mathrm{Cl}$ counter ion competition is important and after that micellar shape is important. The reason is same for $\mathrm{NaCl}$ up to $0.8 \mathrm{~mol} \cdot \mathrm{L}^{-1}$.

\section{Conclusions}

Kinetics and mechanism of chromic acid reduction by butan-1-ol in aqueous acid media have been studied under the conditions $[\text { butan-1-ol }]_{\mathrm{T}}>[\mathrm{Cr}(\mathrm{VI})]_{\mathrm{T}}$. Under the kinetic conditions, the monomeric species of $\mathrm{Cr}(\mathrm{VI})$ has been found kinetically active. Cr(VI)-substrate ester experiences a redox decomposition through 2 electron transfer at the rate determining step. The reaction shows both $1^{\text {st }}$ order dependency on [butan-1-ol $]_{\mathrm{T}}$ and $[\mathrm{Cr}(\mathrm{VI})]_{\mathrm{T}}$

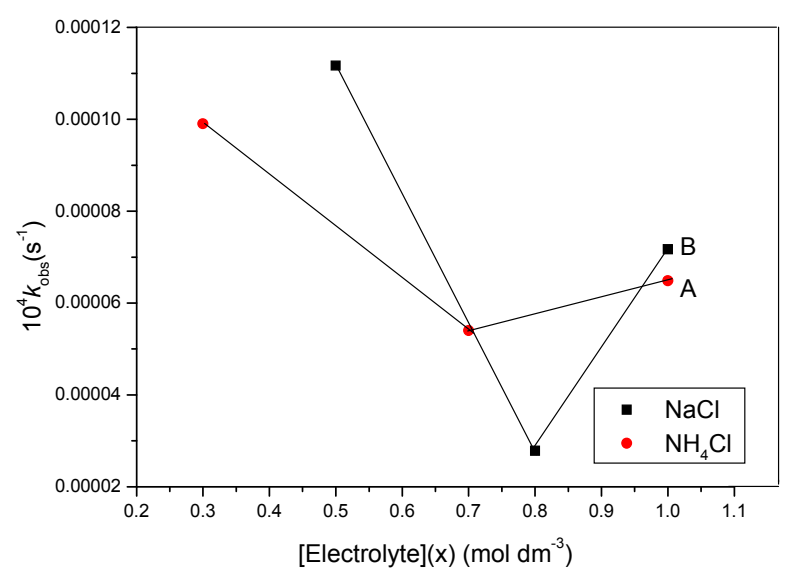

Figure 7. Dependence of $\boldsymbol{k}_{\mathrm{obs}}$ on [electrolyte(x)] for the $\mathrm{Cr}(\mathrm{VI})$ oxidation of 1-butanol at $30^{\circ} \mathrm{C}$ in SDS medium. $[\mathrm{Cr}(\mathrm{VI})]=5$ $\times 10^{-4} \mathrm{~mol} \cdot \mathrm{L}^{-1},[1-$ butanol $]=1500 \times 10^{-4} \mathrm{~mol} \cdot \mathrm{L}^{-1},\left[\mathrm{H}_{2} \mathrm{SO}_{4}\right]=$ $0.50 \mathrm{~mol} \cdot \mathrm{L}^{-1}$. A: $x=\left[\mathrm{NH}_{4} \mathrm{CL}\right] . \mathrm{B}: \mathrm{x}=[\mathrm{NaCl}]$.

and second order dependency on $\left[\mathrm{H}^{+}\right]$ion. In the presence of non-functional surfactant, the order of the reaction remains unaltered. $\mathrm{CPC}$ has been found to retard the rate while SDS and TX-100 shows rate acceleration effect. The effect of added electrolyte is inhibition followed by enhancement in the rate.

\section{Acknowledgements}

Financial support from UGC, New Delhi is thankfully acknowledged. Co-operation from Dr. Bholanath Mandal of this department is thankfully acknowledged.

\section{References}

[1] V. Sarin and K. K. Pant, Removal of Chromium from Industrialwaste by Using Eucalyptus Bark, Bioresource Technology, Vol. 97, No. 1, 2006, pp. 15-20.

[2] D. Park, Y. S. Yun and J. M. Park, "Use of Dead Fungal Biomass for the Detoxification of Hexavalent Chromium: Screening and Kinetics," Process Biochemistry, Vol. 40, No. 7, 2005, pp. 2559-2565.

[3] Z. Kowalski, "Treatment of Chromic Tannery Wastes," Journal of Hazardous Materials, Vol. 37, No. 1, 1994, pp. 137-144.

[4] U. Thacker, R. Parikh and Y. Shouche, D. Madamwar, Hexavalent Chromium Reduction by Providencia sp., Process Biochemistry, Vol. 41, No. 6, 2006, pp. 13321337.

[5] J. T. O'Brien, J. L. Fornsaglio, S. Ceryak, R. S. Patierno, Effects of Hexavalent Chromium on the Survival and Cell Cycle Distribution of DNA Repair-Deficient $S$. cerevisiae, DNA Repair, Vol. 1, No. 8, 2002, pp. 617-627.

[6] P. Pattanapipitpaisal, A. N. Mabbett, J. A. Finalay, A. J. 
Beswick, M. Paterson-Beedle and A. Essa, "Reduction of $\mathrm{Cr}(\mathrm{VI})$ and Bioaccumulation of Chromium by Gram Positive and Gram Negative Microorganisms not Previously Exposed to CR-Stress, Environmental Technology, Vol. 23, No. 7, 2002, pp. 731-745.

[7] A. N. Mabbett and L. E. Macaskie, "A Novel Isolate of Desulfovibrio sp. with Enhanced Ability to Reduce Cr(VI)," Biotechnology Letters, Vol. 23, No. 9, 2001, pp. 683-687.

[8] W. A. Smith, W. A. Apel and J. N. Petersen, "Effect of Carbon and Energy Source on Bacterial Chromate Reduction," Bioremediation Journal, Vol. 6, No. 3, 2002, pp. 205-215.

[9] J. V. Bhinde, P. K. Dhakephalkar and K. M. Paknikar, "Microbiological Process for the Removal of Cr(VI) from Chromate Bearing Cooling Tower Effluent," Biotechnology Letters, Vol. 18, No. 6, 1996, pp. 667-672.

[10] S. S. Ahluwalia and D. Goyal, "Microbial and Plant Derived Biomass for Removal of Heavy Metals from Wastewater," Bioresouce Technology, Vol. 98, No. 12, 2007, pp. 2243-2257.

[11] X. Zhou, T. Korenaga, T. Takahashi, T. Moriwake and S. Shinoda, "A Process Monitoring/Controlling System for the Treatment of Wastewater Containing Chromium(VI)," Water Research, Vol. 27, No. 6, 1993, pp. 1049-1054.

[12] M. Islam, B. Saha and A. K. Das, "Kinetics and Mechanism of 2,2'-Bipyridyl and 1,10-PhenanthrolineCatalysed Chromium(VI) Oxidation of D-Fructose in Aqueous Micellar Media," Journal of Molecular Catalysis A: Chemical, Vol. 236, No. 1-2, 2005, pp. 260-266.

[13] M. Islam, B. Saha and A. K. Das, "Kinetics and Mechanism of Picolinic Acid Promoted Chromic Acid Oxidation of Maleic Acid in Aqueous Micellar Media," Journal of Molecular Catalysis A: Chemical, Vol. 266, No. 1-2, 2007, pp. 21-30.

[14] S. Ghosh, A. Basu, K. K. Paul and B. Saha, "Micelle Catalyzed Oxidation of Propan-2-ol to Acetone by Penta-Valent Vanadium in Aqueous Acid Media," Molecular Physics, Vol. 107, No. 7, 2009, pp. 615-619.

[15] A. Basu, T. Ghosh and B. Saha, "Effect of some Non Functional Surfactants and Electrolytes on the Chromium(VI) Reduction by Glycerol: A Mechanistic Study," International Journal of Chemical Kinetics, (manuscript has sent for consideration).

[16] V. R. Bhalerao and F. A. Kummerow, "Paper Chromatography of 2,4-Dinitrophenylhydrazones of Saturated Aliphatic Aldehydes," Vol. 36, No. 10, 1959, pp. 461-463.

[17] C. A. Bunton and G. Cerichelli, "Micellar Effects upon Electron Transfer from Ferrocenes," International Journal of Chemical Kinetics, Vol. 12, No. 8, 1980, pp. 519-533.

[18] F. M. Menger and C. E. Portnoy, "Chemistry of Reac- tions Proceeding inside Molecular Aggregates," Journal of the American Chemical Society, Vol. 89, No. 8, 1967, pp. 4698-4703.

[19] J. W. Mc Bain, "Colloids and their Viscosity," Transactions of the Faraday Society, Vol. 9, 1913, pp. 34-46.

[20] G. S. Hartle, "The application of the Debye-Hückel Theory to Colloidal Electrolytes," Transactions of the Faraday Society, Vol. 31, 1935, pp. 31-50.

[21] J. W. Mc Bain, "Colloid Chemistry, Theoretical and Applied, In: J. Alexander, Ed., New York, 1944.

[22] R. H. Mattan, R. S. Stearns and W. D. Harkins, "Structure for Soap Micelles as Indicated by a Previously Unrecognized X-Ray Diffraction Band," Journal of Chemical Physics, Vol. 15, 1947, pp. 209-210.

[23] W. D. Harkins, "A Cylindrical Model for the Small Soap Micelle," Journal of Chemical Physics, Vol. 16, 1948, pp. 156-157.

[24] P. Debye and E. W. Anacker, "Micelle Shape from Dissymmetry Measurement," Journal of Physical Chemistry, Vol. 55, No. 5, 1951, pp. 644-655.

[25] I. Reich, "Factors Responsible for the Stability of Detergent Micelles," Journal of Physical Chemistry, Vol. 60, No. 3, 1956, pp. 257-262.

[26] C. A. Bunton, "Reaction Kinetics in Aqueous Surfactant Solutions," Catalysis Reviews, Science and Engineering, Vol. 20, No. 1, 1979, pp. 1-56.

[27] H. Morawetz, "Catalysis and Inhibition in Solutions of Synthetic Polymers and in Micellar Solutions," Advances in Catalysis \& Related Subject, Vol. 20, In: D. D. Eley, Ed., Academic Press, New York, 1969, pp. 341-371.

[28] E. M. Cordes and R. B. Dunlop, "Kinetics of Organic Reactions in Micellar Systems," Accounts of Chemical Research, Vol. 2, No. 11, 1969, pp. 329-337.

[29] E. J. Fendler and J. H. Fendler, "Micellar Catalysis in Organic Reactions: Kinetic and Mechanistic Implications," Advances in Physical Organic Chemistry, Vol. 8, 1970, pp. 271-406.

[30] C. A. Bunton, M. Minch and L. Sepulveda, "Enhancement of Micellar Catalysis by Added Electrolyte," Journal of Physical Chemistry, Vol. 75, No. 17, 1971, pp. 2707-2709.

[31] A. K. Das, "Micellar Effect on the Kinetics and Mechanism of Chromium(VI) Oxidation of Organic Substrates," Coordination Chemistry Reviews, Vol. 248, No. 1-2, 2004, pp. 81-99.

[32] K. J. Mysels and L. H. Princen, "Light Scattering by Ideal Colloidal Electrolyte," Journal of Colloid Science, Vol. 12, No. 6, 1957, pp. 594-605.

[33] K. Shinoda, "The Critical Micellar Concentrations in Aqueous Solutions of Potassium Alkyl Malonates," Journal of Physical Chemistry, Vol. 59, No. 5, 1955, pp. 432-435. 